\title{
Penetapan Kadar Senyawa Fitokimia (Tanin, Saponin Dan Flavonoid Sebagai Kuersetin) Pada Ekstrak Daun Inggu (Ruta angustifolia L.)
}

\author{
Shafa Noer, Rosa Dewi Pratiwi, Efri Gresinta \\ Pendidikan Biologi, Fakultas Teknik dan MIPA \\ Universitas Indraprasta PGRI Jakarta \\ shafa_noer@yahoo.co.id
}

\begin{abstract}
ABSTRAK
Secara empiris daun Inggu (Ruta angustifolia L.) berpotensi untuk dijadikan bahan baku obat tradisional karena mengandung zat fitokimia. Organ utama yang paling banyak digunakan sebagai obat tradisional adalah daunnya. Senyawa fitokimia yang terkandung dalam daun inggu antara lain flavonoid sebagai kuersetin, tannin dan saponin. Flavonoid adalah senyawa yang terdiri dari 15 atom karbon yang berfungsi sebagai pigmen tanaman. Fungsi flavonoid yaitu melindungi struktur sel, meningkatkan efektifitas vitamin $C$, antiinflamasi dan sebagai antibiotik. Sedangkan saponin dan tanin merupakan golongan senyawa aktif tumbuhan yang bersifat fenol, mempunyai rasa sepat dan memiliki aktivitas antibakteri. Penelitian ini bertujuan untuk mengetahui kadar flavonoid, tannin dan saponin yang terdapat dalam daun Inggu. Preparasi sampel daun inggu dilakukan dengan teknik ekstraksi maserasi dengan pelarut etanol 96\%. Analisis kadar tannin dan flavonoid sebagai kuersetin ditentukan dengan Spektrofotometri UVVisibel pada panjang gelombang $(\lambda) 725 \mathrm{~nm}$. Sedangkan analisis kadar saponin menggunakan TLC Scanner. Hasil analisis menunjukkan kadar flavonoid daun inggu sebagai kuersetin sebesar 1,67\%; saponin sebesar 2,13\% dan tannin sebesar 7,04\%.
\end{abstract}

Kata-kata kunci : Ruta angustifolia, fitokimia, flavonoid, tannin, saponin.

\begin{abstract}
Empirically, Inggu leaves (Ruta angustifolia L.) has potential to be used as raw material of traditional medicine because it contains phytochemical substances. The main organ most widely used as a traditional medicine is its leaves. Phytochemical compounds contained in the leaves of inggu include quercetin, tannin and saponins. Quercetin is a class of flavonol compounds (part of flavonoids). Quercetin has the ability to prevent the oxidation process from low density lipoprotein (LDL) by capturing free radicals and inhibiting transition metals, so that quercetin is believed to protect the body from various degerative diseases. While flavonoids are compounds consisting of 15 carbon atoms that act as plant pigments. The function of flavonoids is to protect the cell structure, increase the effectiveness of vitamin $\mathrm{C}$, antiinflammatory and as an antibiotic. While saponin and tannin are a group of active compounds of plants that have a sense of bitter and have antibacterial activity. This study was aim to determine the number of quercetin, tannins and saponins contained in the inggu's leaves. Preparation of inggu leaf sample was done by maceration extraction technique used $96 \%$ ethanol solvent. Analysis of tannin and quercetin levels was determined by UV-Visible Spectrophotometry at $725 \mathrm{~nm}$ wavelength $(\lambda)$. While the analysis of saponin content using TLC Scanner at $301 \mathrm{~nm}$ wavelength $(\lambda)$. The results showed that content of quercetin was $1.67 \%$; saponins $2.13 \%$ and tannins $7.04 \%$.
\end{abstract}

Keywords: Ruta angustifolia, phytochemical, quercetin, tannin, saponins.

Penetapan Kadar Senyawa Fitokimia (Tanin, Saponin Dan Flavonoid Sebagai Kuersetin) Pada Ekstrak Daun Inggu (Ruta angustifolia L.) 


\section{Pendahuluan}

Indonesia merupakan salah satu negara yang telah dikenal merupakan salah satu Negara yang mempunyai keanekaragaman hayati tinggi. Keberadaan hutan yang luas dan iklim tropis yang mendukung menjadi salah satu pemicu tumbuhnya berbagai macam flora di Indonesia. Dari sekian banyak flora yang tumbuh di Indonesia tersebut, ribuan diantaranya telah dikenal oleh masyarakat Indonesia berkhasiat sebagai obat dan digunakan untuk mengobati banyak penyakit.

Sejak lebih dari puluhan tahun yang lalu, masyarakat dunia, tidak saja di negaranegara Timur melainkan juga di negaranegara Barat, mulai menoleh kembali dan tertarik untuk menggunakan obat-obat alam, yang kita kenal sebagai gerakan Kembali ke Alam atau Back to Nature. Adanya ketertarikan terhadap pola hidup Kembali ke Alam ini salah satunya disebabkan oleh keyakinan bahwa mengkonsumsi obat alami relatif lebih aman dibanding dengan obat sintetik yang memiliki banyak efek samping negatif.

Namun sayangnya, karena bahan baku yang sulit didapatkan atau peralatan yang digunakan untuk mengolah, saat ini harga obat tradisional di pasaran tidak bisa dikatakan murah atau bahkan beberapa bisa dapat lebih mahal dari obat sintetik. Salah satu strategi yang dapat dilakukan adalah memberdayakan masyarakat agar dapat mengolah obat tradisional alaminya secara mandiri, mulai menanam tumbuhan obatnya sampai mengolahnya menjadi ramuan obat siap pakai dalam bentuk sederhana. Ramuan obat yang diolah segar tentu saja memiliki khasiat lebih baik dibandingkan dengan yang sudah disimpan lama (Sinaga, 2009 : 1).

Tanaman Ruta angustifolia atau yang biasa disebut dengan tanaman Inggu telah lama dipercaya dan digunakan oleh masyarakat Indonesia sebagai obat untuk berbagai macam penyakit. Organ utama yang paling banyak digunakan sebagai obat tradisional adalah daunnya. Cara pengolahan daun sebelum menjadi ramuan obat berbagai macam, namun yang paling sederhana adalah menggunakan daun langsung dengan menghancurkannya dan menempelkan pada tempat yang sakit. Atau cara lain adalah dengan merebus beberapa helai daun inggu sampai air menjadi

Penetapan Kadar Senyawa Fitokimia (Tanin, Saponin Dan Flavonoid Sebagai Kuersetin) Pada Ekstrak Daun Inggu (Ruta angustifolia L.) 
setengahnya lalu diminum secara rutin. Penyakit yang dipercaya dapat diatasi dengan ramuan daun inngu meliputi penyakit gigi, semam, kejang pada anak, nyeri ulu hati, merangsang haid, kecekukan, sakit kepala dan bisul.

Tanaman ini memiliki ciri : Habitus berupa semak, tinggi $\pm 1,5 \mathrm{~m}$, batang berkayu berbentuk bulat, percabangan simpodial,dan berwarna hijau muda. Daun majemuk, anak daun lanset atau bulat telur, pangkal runcing, ujung tumpul, tepi rata, panjang 8-20 $\mathrm{mm}$, lebar 2-6 $\mathrm{mm}$, pertulangan tidak jelas, berwarna hijau. Bunga majemuk, kelipak bentuk segitiga, berwarna hijau, putik satu, kuning, benang sari delapan, duduk pada dasar bunga, kepala sari kuning, mahkota bentuk mangkok, kuning. Buah kecil, lonjong, terbagi menjadi 4, berwarna coklat. Biji berbentuk ginjal, kecil, berwarna hitam. Akar tunggang, bulat, bercabang, warna putih kekuningan (Aspan dkk, 2008).

Tanaman ini rasanya pedas, agak pahit, dan berbau tajam. Ekstrak daun Ruta angustifolia telah secara umum digunakan oleh masyarakat Cina di Malaysia dan Singapura dalam pengobatan kanker (Richardson dkk, 2016).
Ekstrak dari Ruta angustifolia (etanol, heksana, diklorometana dan metanol) baru-baru ini dilaporkan menunjukkan aktivitas anti-virus. Ia menunjukkan aktivitas anti-viral terhadap hepatoma cell line (Huh7.5) dengan nilai $\mathrm{IC}_{50}$ berkisar antara 1,6-15,6 $\mu \mathrm{g} / \mathrm{ml}$ (Wahyuni dkk, 2014).

Dalam penelitian ini peneliti ingin mengetahui seberapa banyak kandungan senyawa kimiawi flavonoid, tannin dan saponin dalam daun inggu yang potensial digunakan sebagai obat. Dengan demikian, hasil penelitian diharapkan bisa menjelaskan secara ilmiah manfaat alami dari daun inggu beserta hubungannya dengan pengobatan beberapa penyakit. Penelitian ini diharapkan bisa menjadi dasar diadakannya penelitian lanjutan tentang potensi daun inggu bagi kesehatan.

\section{Tujuan Penelitian}

Penelitian ini dilakukan untuk mengetahui seberapa besar kadar dari senyawa fitokimia yang terdapat dalam ekstrak daun Inggu (Ruta angustifolia) khususnya flavonoid, tannin dan saponin.

\section{Metode Penelitian}

Penetapan Kadar Senyawa Fitokimia (Tanin, Saponin Dan Flavonoid Sebagai Kuersetin) Pada Ekstrak Daun Inggu (Ruta angustifolia L.) 
1. Pembuatan Ekstraksi Daun Inggu

1.1. Proses Pengeringan

Daun inggu sebanyak $2 \mathrm{~kg}$ yang akan dijadikan sampel, diambil dari perkebunan Tanaman Obat di Lembang, Bandung. Perlakuan terhadap daun Inggu yaiu: 1) Mencuci daun inggu dengan air mengalir sampai bersih, 2) Mengeringkan daun inggu dengan cara diangin-anginkan dan tidak terkena sinar matahari secara langsung selama 5 hari, 3) Mengoven daun Inggu menggunakan wadah aluminium selama 24 jam pada suhu $50^{\circ} \mathrm{C}$.

\subsection{Metode Ekstraksi}

Sebanyak 700 gram daun Ingu kering dipisahkan kedalam 4 botol toples dengan berat masing-masing 200 gram dalam 3 botol dan 1 botol lainnya berisi 100 gram, kemudian di ekstraksi dengan cara maserasi (tanpa panas) dengan menggunakan pelarut etanol 96\% selama 24 jam dengan cara digoyang (shaker) dan diulang 3 kali (3 x 24 jam). Setiap 24 jam filtrat etanol dipisahkan kemudian dipekatkan dengan vakum evaporator. Ekstrak pekat etanol kemudian di timbang bobotnya.

\section{Cara Kerja Penetapan Kadar Senyawa Fitokimia}

2.1. Identifikasi Senyawa Flavonoid, tannin dan saponin pada daun Inggu (Franswort, 1996).

Uji fitokimia kandungan senyawa aktif dilakukan secara kualitatif. Sebanyak 0,5 g fraksi aktif dilarutkan dalam $10 \mathrm{ml}$ air dan dipanaskan diatas penangas air kemudian larutan tersebut dibagi kedalam tiga tabung. Tabung 1) Sebanyak lebih kurang $100 \mathrm{mg}$ serbuk magnesium dimasukkan kedalam tabung pertama lalu ditambah $1 \mathrm{ml}$ asam klorida pekat dan 3 $\mathrm{ml}$ amil alkohol, dikocok kuat dan dibiarkan memisah. Warna merah, kuning, jingga pada lapisan amil alkohol menunjukkan adanya flavonoid. Tabung 2) Tabung kedua dikocok secara vertikal selama 10 detik, maka akan terbentuk busa stabil, dibiarkan selama 10 menit, ditambahkan 1 tetes asam klorida $1 \%$, Jika busa tidak hilang maka menunjukkan adanya saponin. Tabung 3) ditambahkan beberapa tetes larutan besi (III) klorida $1 \%$, terbentuknya larutan warna biru tua atau hijau kehitaman menunjukkan adanya tannin.

Penetapan Kadar Senyawa Fitokimia (Tanin, Saponin Dan Flavonoid Sebagai Kuersetin) Pada Ekstrak Daun Inggu (Ruta angustifolia L.) 
2.2. Uji Kuantitatif kandungan kadar Flavonoid Pada daun Inggu

Ekstrak etanol daun Inggu (Ruta angustifolia) sebanyak $200 \mathrm{mg}$ dimasukan dalam labu takar $100 \mathrm{~mL}$. Ekstrak digenapkan dengan akuades sampai batas atas labu takar. Mengambil $5 \mathrm{~mL}$ dari stok larutan yang dibuat diatas dengan pipet dan memasukannya ke dalam labu takar $10 \mathrm{~mL}$, kemudian menambahkan $500 \mu \mathrm{l}$ reagent Folin Cialcoteu, dikocok selama 1 menit. Sebelum menit ke delapan ditambahkan 4 $\mathrm{mL}$ natrium karbonat $\left(\mathrm{Na}_{2} \mathrm{CO}_{3}\right) \quad 10 \%$ dan dikocok selama 1 menit, kemudian digenapkan dengan akuades sampai batas volume labu takar. Deret standar dibuat dengan konsentrasi 0 ppm, 1 ppm, 2 ppm, 3 ppm, 4 ppm dan 5 ppm dari standar induk asam tanat $100 \mathrm{ppm}$. Setelah itu, diukur absorbansinya pada panjang gelombang $725 \mathrm{~nm}$ menggunakan UV-Vis.

Persamaaan regresi :

$\mathrm{y}=\mathrm{a}+\mathrm{bx} \longrightarrow \mathrm{x}=(\mathrm{y}-\mathrm{a}) / \mathrm{b}$

Dimana,

$\mathrm{x}=$ absorbansi

$\mathrm{b}=$ slope

$\mathrm{y}=$ absorbansi standart

$\mathrm{a}=$ intersep (titik pertemuan $\mathrm{x}$ dan $\mathrm{y}$ )

\subsection{Cara Kerja Penetapan Kadar Saponin}

1) Menimbang sampel 0,25 gram kedalam labu ukur $25 \mathrm{~mL}$. 2) Menambahkan akuades sebanyak sepertiga volume labu ukur. 3) Mengocoknya selama 2 jam. 4) Menyaring suspensi yang dihasilkan. 5) Menotolkan filtrate kedalam lempeng TLC sebanyak 5 $\mu 1.6)$ Membuat standar saponin $100 \mathrm{ppm}$ dan menotolkannya sebanyak $5 \mu$ l. 7) Mengelusi campuran tersebut dengan eluen $\mathrm{CHCl}_{3}$ : etanol: etil asetat selama 45 menit. 8) Mengukur dengan Scanner TLC pada panjang gelombang $(\lambda) 301 \mathrm{~nm}$.

\subsection{Cara Kerja Penetapan Kadar Tanin.}

1) Menimbang 2 gram sampel kedalam labu didih $500 \mathrm{~mL}$, kemudian menambahkan $350 \mathrm{~mL}$ akuades dan merefluks selama 3 jam. 2) Mendinginkan sampel dan memindahkan secara kuantitatif kedalam labu ukur $500 \mathrm{ml}$. 3) Menyaring sampel dan mengambil filtrate sebanyak $2 \mathrm{ml}$ untuk dimasukkan ke dalam labu ukur $100 \mathrm{ml} .4$ ) Menambahkan $2 \mathrm{ml}$ pereaksi Folin Denis dan $5 \mathrm{ml} \mathrm{Na}_{2} \mathrm{CO}_{3}$ jenuh. 5) Membiarkannya selama 40 menit dan mengukur absorbansinya pada panjang gelombang 725 nm. 6) Menambahkan 100 gram Natrium tungstat $\left(\mathrm{Na}_{2} \mathrm{WO}_{4}\right), 20$ gram asam phospomolibdat dan $50 \mathrm{ml}$ asam phospat $85 \%$ kedalam $750 \mathrm{ml}$ akuades kemudian di

Penetapan Kadar Senyawa Fitokimia (Tanin, Saponin Dan Flavonoid Sebagai Kuersetin) Pada Ekstrak Daun Inggu (Ruta angustifolia L.) 
refluks selama 3 jam, mendinginkan dan menambahkan akuades sampai 1 liter. 7) Menambahkan 3 gram $\mathrm{Na} 2 \mathrm{CO} 3$ anhidrat kedalam $100 \mathrm{ml}$ akuades pada suhu 70-80, kemudian mengaduk sampai larut, kemudian mendinginkannnya semalam.

\begin{tabular}{|c|c|c|c|c|}
\hline \multirow[t]{2}{*}{ Botol } & \multicolumn{3}{|c|}{$\begin{array}{c}\text { Volume Etanol } \\
96 \% \text { (liter) }\end{array}$} & \multirow[t]{2}{*}{$\begin{array}{l}\text { Jumlah } \\
\text { (liter) }\end{array}$} \\
\hline & I & II & III & \\
\hline 1 & 1,5 & 1,5 & 1,5 & 4,5 \\
\hline 2 & 1,2 & 1,2 & 1,2 & 3,6 \\
\hline 3 & 1,0 & 1,0 & 1,0 & 3,0 \\
\hline 4 & 1,2 & 1,2 & 1,2 & 3,6 \\
\hline \multicolumn{4}{|c|}{ TOTAL } & 14,7 \\
\hline
\end{tabular}

Melarutkan $100 \mathrm{mg}$ asam tanat dengan 100 $\mathrm{ml}$ akuades, mengocoknya setiap akan melakukan running pada UV-Vis. 8) Menambahkan $2 \mathrm{ml}$ pereaks Folin Denis kedalam labu ukur $100 \mathrm{ml}$ yang telah diisi 50-70 ml akuades, memipet sebanyak 0,3 : $0,6: 0,9 ; 1,2$ dan $1,5 \mathrm{ml}$ lartan standar asam tanat kemudian menambahkan $5 \mathrm{ml}$ larutan $\mathrm{Na}_{2} \mathrm{CO}_{3}$ jenuh kedalam masing-masing labu dan menempatkannya hingga $100 \mathrm{ml}$ dengan akuades. 9) Membiarkannya selama 40 menit sebelum diukur absorbansinya pada panjang gelombang $725 \mathrm{~nm}$ untuk dibuat kurva standarnya.

\section{Pembahasan}

Sampel daun Ruta angustifolia (inggu) dalam penelitian ini dipanen dari Penetapan Kadar Senyawa Fitokimia (Tanin, Saponin Dan Flavonoid Sebagai Kuersetin) Pada Ekstrak Daun Inggu (Ruta angustifolia L.)
Kebun Percobaan Balitro Monako, Lembang, Bandung. Sampel setengah kering sebanyak $2 \mathrm{~kg}$ kemudian dikeringkan lebih lanjut menggunakan oven sampai tekstur daun menjadi serbuk dan didapat sampel kering sebanyak 700 gr. Dari sampel kering daun Inggu kemudian didapatkan ekstrak pekat hasil maserasi daun inggu menggunakan pelarut etanol 96\% sebanyak 14,7 L.

Tabel 1. Volume etanol $96 \%$ yang digunakan pada proses ekstraksi.

Penelitian ini diulangi 3 kali untuk mendapatkan hasil yang valid. Setelah dikeringkan lebih lanjut, didapat sebanyak 221,81 gr ekstrak dengan rendemen 31,69 \%. Dari hasil ekstrak pekat ini kemudian dilakukan analisis kandungan kimiawi (skrining fitokimia) secara kualitatif dan kuantitatif untuk flavonoid, tannin dan saponin.

Secara kualitatif senyawa flavonoid terbukti ada dalam daun Inggu. Sebagian besar flavonoid yang terdapat pada tumbuhan terikat pada gula sebagai glikosidanya dan dalam bentuk campuran atau jarang sekali ada sebagai senyawa tunggal. Flavonoid mempunyai kerangka 
dasar karbon yang terdiri dari 15 atom karbon. Dimana dua cincin benzena (C6) terikat oleh rantai propana (C3). Gambar 1 menyajikan salah satu jenis senyawa flavonoid.

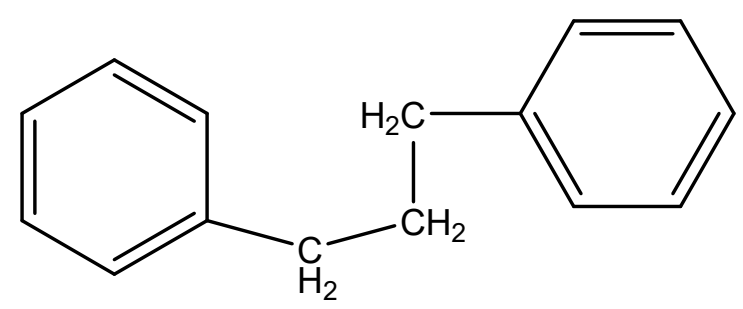

Gambar 1. Struktur Dasar Flavonoid

Setelah ekstrak di tambahkan dengan logam magnesium, asam klorida $(\mathrm{HCl})$ memberikan warna merah. Kemungkinan golongan flavonoidnya adalah flavanon, flavanonol dan flavanol. Reaksi antara senyawa flavonon dengan logam magnesium sebagai berikut (Gambar 2):

$2 \mathrm{C}_{2} \mathrm{H}_{5} \mathrm{OH}+2 \mathrm{Mg} \rightarrow \mathrm{Mg}(\mathrm{OH})_{2}+$ $\mathrm{C}_{2} \mathrm{H}_{5} \mathrm{Mg}(\mathrm{OH})_{2}+\mathrm{C}_{2} \mathrm{H}_{5}+\mathrm{HCl}$
Gambar 2. Reaksi Flavonon dengan etanol

Sedangkan untuk uji kuantitatif, pada penelitian ini menggunakan UV-vis didapatkan kadar flavonoid sebagai kuersetin sebesar 1,67\%. Kadar sebesar $1,67 \%$ ini tergolong sedang dibandingkan dengan kadar flavonoid pada tanaman lain. Nugraha, A dan Ghozali (2012) menentukan kandungan flavonoid dalam kuersetin pada ekstrak kulit buah apel hijau menggunakan metode HPLC (High Performance Liquid Chromatography). Hasil penelitiannya menunjukkan bahwa kadar rata-rata kuersetin flavonoid pada ektrak etanol kulit buah apel hijau adalah 0,0143\%, yang berate setiap 100 gram ekstrak mengandung 0,0143 gram kuersetin flavonoid.

Berbeda dengan penelitian Nugraha, A dan Ghozali (2012), Mirna Lumbessy dkk (2015) mengidentifikasi kandungan

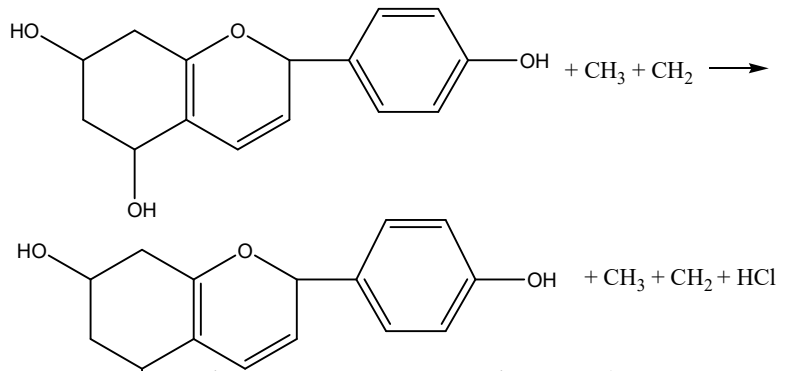
flavonoid dari beberapa daun yaitu daun waru, ketepeng, pegagan, rumput teki dan rumput mutiara. Kadar flavonoid tertinggi sebesar 26,863 mg/ml pada daun ketepeng dan yang terendah sebesar 1,425 mg/ml Penetapan Kadar Senyawa Fitokimia (Tanin, Saponin Dan Flavonoid Sebagai Kuersetin) Pada Eksträk Daun Inggu (Ruta angustifolia L.) 
pada daun waru. Dari uraian diatas menunjukkan adanya kesamaan hasil dari penelitian yang telah dilakukan dengan penelitian sebelumnya yaitu ekstrak daun inggu memiliki senyawa aktif seperti flavonoid dengan kadar rendah yaitu 1,67 $\mathrm{mg} / \mathrm{ml}$ yang berpotensial sebagai bahan baku obat.

Berbeda dengan flavonoid, tannin adalah salah satu golongan senyawa polifenol yang juga banyak dijumpai pada tanaman. Tanin dapat didefinisikan sebagai senyawa polifenol dengan berat molekul yang sangat besar yaitu lebih dari 1000 $\mathrm{g} / \mathrm{mol}$ serta dapat membentuk senyawa kompleks dengan protein. Dari Gambar 3 terlihat bahwa struktur senyawa tannin terdiri dari cincin benzena (C6) yang berikatan dengan gugus hidroksil $(-\mathrm{OH})$. Tanin memiliki peranan biologis yang besar karena fungsinya sebagai pengendap protein dan penghelat logam. Oeh karena itu tannin diprediksi dapat berperan sebagai antioksidan biologis.

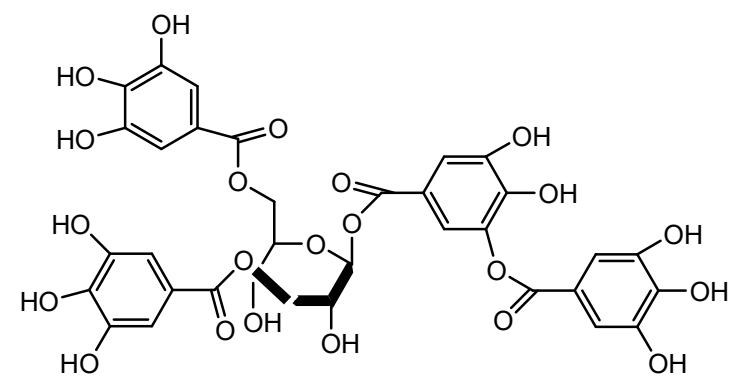

\section{Gambar 3. Struktur Tanin}

Sama halnya dengan struktur senyawa tannin, saponin juga memiliki berat molekul yang relatif tinggi.

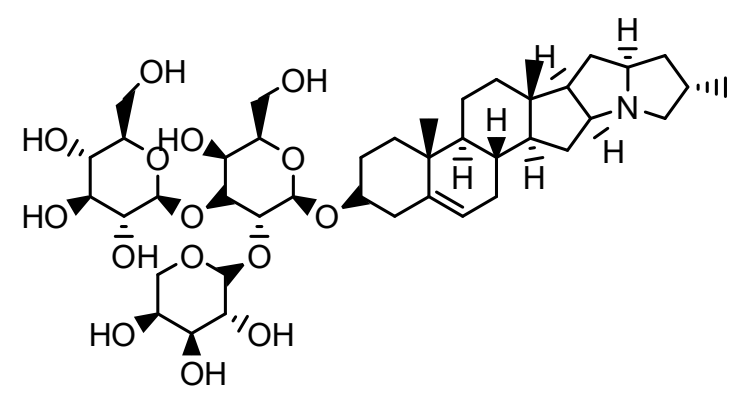

Gambar 4. Struktur Saponin

Dalam penelitian ini, kadar tannin dalam ekstrak daun inggu sebesar 7,04\% dan saponin sebesar 2,13\%. Kadar senyawa fitokimia dalam daun inggu dapat dikategorikan sedang dibandingkan hasil penelitian pada tumbuhan lain.

Hasil penelitian ini sejalan dengan Fania (2013) yang menyatakan bahwa daun inggu mengandung senyawa aktif seperti alkaloid, kumarin, flavonoid, dan terpenoid setelah diuji dengan Kromatografi Lapis Tipis (KLT).

$$
\text { Sedangkan Windy }
$$
menjelaskan bahwa secara kualitatif ekstrak daun inggu mengandung metabolit sekunder yaitu triterpenoid, flavonoid, saponin, tannin, polifenol dan alkaloid. Ekstrak daun inggu yang dihasilkan

Penetapan Kadar Senyawa Fitokimia (Tanin, Saponin Dan Flavonoid Sebagai Kuersetin) Pada Ekstrak Daun Inggu (Ruta angustifolia L.) 
ternyata memiliki aktivitas terhadap bakteri Eschericia coli.

Liberty , dkk (2012) menentukan kandungan tannin pada ekstrak biji alpukat serta menguji aktivitas antioksidan ekstrak biji alpukat segar dan kering. Penentuan kandungan total tanin dilakukan dengan metode Folin Ciocalteau, sedangkan penentuan tanin terkondensasi dilakukan dengan metode Vanilin- $\mathrm{HCl}$ dan aktivitas antioksidan diukur dengan metode DPPH. Hasil penelitian Liberty P, dkk (2012) menunjukkan bahwa kandungan total tanin biji alpukat biasa kering, biji alpukat mentega kering, biji alpukat biasa segar, biji alpukat mentega segar berturut-turut yaitu $117 \mathrm{mg} / \mathrm{kg}$ (0,0117\%), $112 \mathrm{mg} / \mathrm{kg}$ $(0,0112 \%), 41,3335 \mathrm{mg} / \mathrm{kg}(0,00413 \%)$ dan $41 \mathrm{mg} / \mathrm{kg}$ (0,0041\%). Kandungan tanin terkondensasi biji alpukat biasa kering, biji alpukat mentega kering, biji alpukat biasa segar, biji alpukat mentega segar berturutturut yaitu 20,855 mg/kg, 16,966 mg/kg, $5,411 \mathrm{mg} / \mathrm{kg}$ dan 4,411 mg/kg. Jika dibandingkan dengan kadar tannin pada daun inggu dengan kandungan tannin 7, 04\% maka dapat disimpulkan kadar tannin pada daun inggu lebih tinggi dibandingkan pada biji alpukat.
Disisi lain, saponin yang terdapat dalam organ daun inggu jika dibandingkan dengan tumbuhan atau organ lain tergolong rendah. Agung dkk (2015) menyatakan bahwa batang pisang mengandung flavonoid, tannin dan saponin (struktur saponin pada Gambar 4).

Dari pembahasan tersebut dapat dilihat bahwa daun inggu terbukti mengandung senyawa-senyawa kimia yang potensial digunakan sebagai obat-obatan. Penelitian lanjutan untuk membuktikan dan mendukung hasil penelitian ini sangat diperlukan guna mengembangkan daun inggu sebagai bahan obat yang aman dan efektif.

\section{KESIMPULAN}

Berdasarkan hasil penelitian dapat disimpulkan bahwa penetapan kadar secara kuantitatif untuk kandungan total flavonoid, tannin, dan saponin pada ekstrak daun inggu masing-masing yaitu 1,67\%; $7,04 \%$ dan $2,13 \%$.

\section{DAFTAR PUSTAKA}

Agung M, dkk, 2015, Isolasi Dan Identifikasi Senyawa Saponin Dari Ekstrak Metanol Batang Pisang Ambon (Musa paradisiaca var. Sapientum 1.), Pharmacon, 1, 86-92

\section{Penetapan Kadar Senyawa Fitokimia (Tanin, Saponin Dan Flavonoid Sebagai Kuersetin)} Pada Ekstrak Daun Inggu (Ruta angustifolia L.) 
Ajizah, A, 2004, Sensitivitas Salmonella typhimurium Terhadap Ekstrak Daun Psidium guajava L, Bioscientie, 1, 31-38

Akiyama, H. F., K. Iwatsuki, T., 2001, Antibacterial Action Of Several Tennis Agains Staphylococcus aureus, Journal of Antimicrobial Chemoterapy, 48, 487-91

Arief Hariana, 2013，262 Tumbuhan Obat dan Khasiatnya, Penerbit Penebar Swadaya, Jakarta, ISBN : 9789790026131

Aspan Ruslan dkk., 2008, Taksonomi Koleksi Tanaman Obat Kebun Tanaman Obat Citeureup, Penerbit BPOMRI, Jakarta, ISBN : 9789793707426

Bernasconi, G, Penerjemah; Handojo, 1995, Teknologi kimia I, Penerbit Prandya Paramitha, Jakarta, ISBN : .9794083682

Fania Putri Luhurningtyas, 2013, Aktivitas Larvasida Fraksi Non Polar Ekstrak Etanol Daun Inggu Terhadap Larva Nyamuk Anopheles aconitus dan Anopheles maculatus Beserta Profil Kromatografinya, Penerbit UMS, Surakarta,

Franswort, N. R., 1996, Biological and Phytochemical Screenings of Plant, Journal of Pharmacy Science, 55, 225-265

Harborne, J.B., 1996, Metode Fitokimia, ITB press, Bandung, ISBN : 9798001141
Kristiana, Maryani, dan Herti, 2008, Khasiat dan Manfaat Rosela, Penerbit Agro Media Pustaka, Jakarta, ISBN : 9793702737

Liberty P, Meiske S., Jessy P., 2012, Penentuan Kandungan Tanin dan Uji Aktivitas Antioksidan Ekstrak Biji Buah Alpukat (Persea americana Mill.), Jurnal MIPA Unsrat Online, $1,5-10$

Nugraha, Andika dan Ghozali, Penetapan kadar flavonoid kuersetin ekstrak kulit Buah apel hijau (Pyrus malus l.) dengan menggunakan Metode kromatografi cair kinerja tinggi, http://thesis.umy.ac.id/datapublik/t34 235.pdf, Diakses tanggal 13 Desember 2017

Nurachman, Z, 2002, Artoindonesianin Untuk Antitumor, https: //digi lib.itb.ac.id/gdl.php?mod=browse\&o $\mathrm{p}=$ read\&id=jbptitbpp-gdl-web-2006zeilynurac- 1823, Diakses tanggal 13 Desember 2017

Mirna Lumbessy, Jemmy Abidjulu, Jessy J. E. Paendong., 2015, Uji Total Flavonoid Pada Beberapa Tanaman Obat Tradisonal Di Desa Waitina Kecamatan Mangoli Timur Kabupaten Kepulauan Sula Provinsi Maluku Utara, Jurnal MIPA UNSRAT Online, 2, 50-55

Richardson,J.S.M; G. Sethi; G. S Lee and S.N.A Malek., 2016, Chalepin: isolated from Ruta angustifolia L.Pers induces mitochondrial mediated apoptosis in lung carcinoma cells, BMC Complementary and Alternative Medicine, 16, 2-27

Penetapan Kadar Senyawa Fitokimia (Tanin, Saponin Dan Flavonoid Sebagai Kuersetin) Pada Ekstrak Daun Inggu (Ruta angustifolia L.) 
Robinson, T. 1991.Kandungan Organik Tumbuhan Tingkat Tinggi, diterjemahkan oleh Prof. Dr. Kosasih Padmawinata, ITB Press, Bandung, ISBN : 979859147

Sinaga, E., 2009, Mengenal dan Memanfaatkan Tumbuhan Obat untuk Pemeliharaan Kesehatan Sehari-Hari, Pusat Penelitian dan Pengembangan Tumbuhan Obat Universitas Nasional, Jakarta

Wahyuni TS, Widyawaruyanti A, Lusida MI, Fuad A, Fuchino H, Kawahara N, Hayashi Y, Aoki C, Hotta H., 2014, Inhibition of hepatitis $\mathrm{C}$ virus replication by chalepin and pseudane IX isolated from Ruta angustifolia leaves, Fitoterapia, 99, 276-283

Windy, T., Febri O.N., Hermania E.W., 2013, The Antibacterial Activities Of The Extraxts Isolated From The Aruda Leaf (Ruta angustifolia) Digested In Polar Semipolar Dan Nonpolar Solvent, Journal of applied chemistry science, $2,1-20$

Penetapan Kadar Senyawa Fitokimia (Tanin, Saponin Dan Flavonoid Sebagai Kuersetin) Pada Ekstrak Daun Inggu (Ruta angustifolia L.) 